Висновки. Вивчення стану шкільної й університетської практики дозволяє дійти висновку, що формування готовності майбутніх учителів технологій до навчання школярів декоративно-ужиткового мистецтва (зокрема, художнього оброблення деревини) є однією з важливих передумов цілеспрямованої професійно-педагогічної діяльності, а процес формування цієї готовності у ВНЗ має бути системним, методологічно й дидактично обгрунтованим.

\title{
Література
}

1. Навчальна програма. Трудове навчання 5-9 класи. Нова редакція / укл.: Н. І. Боринець, В. М. Гащак, Р. М. Лещук, В. М. Мадзігон та ін. [Електронний ресурс]. Режим доступу : http://trudove.org.ua/ post/nova-redakts-ya-programi-var-ativn-modul.

2. Навчальна програма «Технології. 10-11 класи» / укл. Н. І. Боринець, С. М. Дятленко, В. К. Сидоренко, Г. В. Терещук та ін. [Електронний ресурс]. - Режим доступу : http://trudove.org.ua/ post/ programi- modul.

3. Навчальна програма «Трудове навчання: основи дизайну» для загальноосвітніх навчальних закладів нового типу: ліцеїв, гімназій, коледжів (5 -9 класи) // Трудова підготовка в закладах освіти. - 2010. - № 9. - С. 13-34; № 10. - С. 29-48; № 11-12. - С. 11-30.

4. Оршанський Л. В. Художньо-трудова підготовка майбутніх учителів трудового навчання : [монографія] / Леонід Володимирович Оршанський. - Дрогобич : Швидко Друк, 2008. -278 с.

Стаття надійшла до редакції 29.05.2012 p.

I. В. Цісарук, асистент, Кременеиький обласний гуманітарно-педагогічний інститут ім. Тараса Шевченка

\section{ОСНОВНІ ПІДХОДИ ДО ПРОБЛЕМИ ОРГАНІЗАЦІЇ ТА ПІДГОТОВКИ САМОСТІЙНӦ̈ РОБОТИ МАЙБУТНІХ УЧИТЕЛІВ ТЕХНОЛОГІЙ}

Цісарук I. В. Основні підходи до проблеми організачії та підготовки самостійної роботи майбутніх учителів технологій.

У статті розкрито основні підходи до проблеми організації самостійної роботи майбутніх фахівиів, проаналізовано роль самостійної роботи на практичних заняттях технологічних дисциплін.

Ключові слова: самостійна робота, практичні заняття, студент, самореалізація.

Цисарук И. В. Основные подходы к проблеме организаџии и подготовке самостоятельной работы будущих учителей технологии.

В статье раскрываются основные подходы к проблеме организачии самостоятельной работы будущих специалистов, проанализирована роль самостоятельной работы на практических занятиях технологических дисицилин.

Ключевые слова: самостоятельная работа, практические занятия, студент, самореализация.

Tsisaruk I. The main approaches to the problem of self-organization and preparation of future teachers of technology.

In the article basic approaches open up to the problem of organization of independent work of future specialists, the role of independent work is analysed on practical employments of technological disciplines.

Key words: independent work, practical employments, student, self-realization. 
Актуальність проблеми. Учитель - це особистість, яка виконує цілеспрямований навчальний та виховний вплив на учнів задля їх особистісного, інтелектуального та діяльнісного розвитку, що стає основою саморозвитку і самовдосконалення особистості [4]. Одним із важливих чинників розвитку та становлення повноцінної особистості, формування загальнотрудових умінь і навичок $\epsilon$ вчитель технологій (у минулому вчитель трудового навчання). Він відіграє головну роль у донесенні до свідомості учнівської молоді таких цінностей, як праця, людина як особистість, що працює.

Необхідність переходу до інноваційної системи освіти зумовлюється тим, що знання, які є сучасними нині, стають застарілими вже через кілька років. Отже, перед нами постає проблема формування в майбутніх учителів технології такого механізму мислення, який би дав можливість їм швидко адаптуватися до вимог, що постійно змінюються, знаходити та аналізувати нові джерела інформації, творчо застосовувати їх у професійній діяльності.

Учитель технологій за роки здобуття освіти має оволодіти великою кількістю вмінь (столярна, слюсарна, швейна справи та художнє оброблення матеріалів), що формуються на практичних заняттях. Під час проведення лабораторних робіт викладач зосереджує значну увагу студента на виконання певних трудових дій, операцій, проектуванні певного виробу. У зв'язку з цим на теоретичну частину заняття відводиться незначна кількість часу, переважно 20-25хв. Отже, раціональна організація самостійної роботи студентів $\epsilon$ запорукою великого успіху в навчанні. Головною метою самостійної роботи $\epsilon$ формування професійно необхідних якостей майбутнього фахівця. Тому методологічним принципом самостійної роботи, як виду навчання у ВНЗ, є професійна спрямованість.

Аналіз останніх досліджень. Фундаментальні науково-педагогічні праці визначають загальні тенденції в організації самостійної роботи студентів. Самостійна робота є складним педагогічним явищем, у дослідженні якого науковці обирають різні напрямки. На теоретичному й методологічному рівнях проблему організації самостійної роботи студентів у процесі оволодіння знаннями розглядали Л. Аристова, В. Буряк, Є. Голант, М. Данилов, Б. Ссипов, Л. Жарова, В. Козаков, Б. Коротяєв, І. Лернер, О. Нільсон, І. Огородников, В. Паламарчук, П. Підкасистий, О. Савченко, А. Усова, Т. Шамова та інші.

Досліджувалися питання розвитку самостійності студентів під час позааудиторної діяльності (О. Дубасенюк, Л. Клименко, В. Лозова, М. Лубенець, Л. Онучак).

Обгрунтування принципів, на основі яких грунтується самостійна робота студентів, спостерігаємо у працях Ю. Бабанського, В. Загвязинського, Ч. Купісевича, В. Оконя, М. Скаткіна та інших. Цікавим $є$ дослідження щодо шляхів формування внутрішньої та зовнішньої мотивації навчальної діяльності. Доведено, що дотримання принципу свідомості, творчої активності та самостійності студентів сприяє ефективності навчання, мотивації засвоєння знань, формуванню навичок і вмінь [2]. 
Мета і завдання дослідження. Метою статті є розкриття основних підходів організації самостійної роботи під час вивчення технологічних дисциплін. Основним завданням є визначення самостійної роботи як одного 3 найефективніших методів формування компетентності майбутнього вчителя технологій.

Виклад основного матеріалу. У педагогічній науці досліджено різні підходи до класифікації самостійної роботи: за умовами виконання; за способом накопичення фактичних знань із предмета; за обов'язковістю тощо.

Проблема підготовки студентів до самостійної роботи й керівництва нею, як зазначає О.Мороз, поділяється на три великі блоки: мотиваційний, технологічний й організаційний. Інакше кажучи, необхідно створити у студентів високу мотивацію до самостійної роботи, організувати відповідну діяльність.

Що стосується першого блоку, то створенню високої мотивації відповідає цілеспрямоване акцентування викладачем особливого значення самостійної роботи серед усіх інших форм навчання. Неабияке значення у цьому зв'язку має визначення достатньої кількості часу на самостійну роботу, що планується як частина навчального процесу. Дуже важливо зацікавити та раціонально розподілити самостійну роботу на першому курсі, адже студенти, не маючи необхідних навичок роботи із деревом, металом, тканиною, при перших невдачах можуть втратити віру в себе і свій вибір професії. Оскільки майбутній учитель технологій має здобути низку практичних умінь та навичок, то викладач безпосередньо має спрямовувати його на постійну роботу над собою та бажання вдосконалюватися. Якщо першокурсники навчаться самостійно організовувати роботу, то на старших курсах викладачу потрібно слідкувати, щоб студенти виконували завдання систематично та $з$ дотриманням усіх вимог.

Мотиваційний аспект через чинник часу тісно пов'язаний 3 організаційним. Йдеться про те, щоб запропонувати студентам обгрунтовані норми часу на ті чи інші форми навчальної роботи, а також визначати їм завдання для самостійної підготовки 3 урахуванням цих норм. Наявність $і$ цілеспрямоване виконання навіть не дуже точних, але погоджених норм дисциплінує й організовує студентів.

Слід зазначити, що додержання студентами психогігієнічних норм порядку дня, створення умов для їх виконання в самому навчальному закладі також $\epsilon$ необхідною передумовою для раціональної організації самостійної роботи й всього навчального процесу.

Не менше значення має й технологічний аспект самостійної роботи. На запитання, що заважає студентам учитись, майже 40 \% студентів називають як основну причину «відсутність уміння самостійно працювати». Низький рівень відповідних умінь і навичок студентів (наприклад, планувати свою самостійну роботу; виконувати порядок дня; орієнтуватися в джерелах знань; конспектувати; збагачуватися новими знаннями; запам'ятовувати необхідні дані; виявляти наполегливість, коли це необхідно; зосереджувати увагу в потрібні моменти тощо) заважає їм засвоїти навіть досить простий 
матеріал. Отже, організатор самостійної роботи студентів має виконати такі завдання: по-перше, обгрунтовано визначити обсяг матеріалу, що виноситься на самостійну роботу; по-друге, ураховувати мотиваційний та технічний аспекти підготовки студентів до неї [5].

Ураховуючи, що передача інформації 3 технологічних дисциплін проводиться в основному на практичних заняттях, і лише іноді в процесі читання лекцій, студент має не тільки активно сприймати інформацію, але й самостійно осмислювати та удосконалювати ії в практичних діях.

Неможливо не зазначити значного внеску у формування самостійності майбутніх учителів технологій, проектно-технологічної діяльності. На практичних заняттях студент учиться використовувати не репродуктивний підхід до виготовлення виробу, а творчий, тобто він, аналізуючи низку поширених моделей, створює власний унікальний проект. Великими перевагами у створенні творчих проектів $є$ те, що студенти самостійно розробляють ескізи, конструкції, технологічну документацію, аналізують економічні витрати, труднощі у виготовленні тощо. Отже, можна сміливо стверджувати, що під час виконання таких проектів відбувається самореалізація та самовдосконалення фахівця.

Також важливо підкреслити вагомість діалогічної взаємодії на практичних заняттях, яка збагачує творчі можливості особистості взаємним обміном ідеями, досвідом і дозволяе виразити та виявити суспільносоціальну сутність студента. При цьому студент набуває здатності співвідносити точку зору з іншими, збагачуючи власну свідомість. Іншими словами, створюються можливості реалізації міжособистісного колективного обговорення варіантів розв'язання проблемного завдання, отриманих у процесі роботи окремими студентами, створюються умови для аналізу позицій студентів групи щодо аргументації правильності чи помилковості як розроблення питання, так і його розуміння. Цим визначається більш високий рівень результативності навчання [3].

Але не потрібно забувати і про значний вплив викладача на організацію самостійної роботи. Тому дослідження організації самостійної роботи студентів обов'язково співвідноситься 3 роллю викладача-організатора. Водночас значна увага надається цілком самостійній роботі студентів, яка має переваги перед самостійною роботою під керівництвом викладача. На думку О. Аксьонової, переваги полягають у тому, що надано можливість студенту зробити глибокий і всебічний аналіз завдання; ознайомитися 3 різними точками зору на певну проблему; студент сам обирає найбільш оптимальний для себе варіант опрацювання матеріалу. Автор наголошує, що навчання - це самоосвіта, яка грунтується на самостійній роботі студентів [1].

Отже, можна вважати, що формування знань, умінь i навичок майбутнього вчителя технологій, передбачених навчальними програмами, забезпечується відповідністю обраних форм, методів і засобів навчання. Самостійна робота як одна з форм організації занять спрямована на розвиток компетентності майбутніх фахівців. 
Висновки. Отже, якщо розглядати самостійну роботу як форму пізнавальної активності суб'єкта, то постає проблема організації самостійної роботи студентів в умовах особистісно зорієнтованого навчання, що є одним зі стратегічних напрямів побудови якісно нової системи підготовки фахівців. Наявні різні підходи щодо проблеми підготовки самостійної роботи, що забезпечують розвиток і самовдосконалення особистості студента на основі врахування його індивідуальних особливостей.

Доведено, що самостійна робота студентів успішно здійснюється за дотримання певних умов: чітко визначено мету і завдання самостійної роботи; усвідомлене ставлення студентів до необхідності самостійної роботи; наявність обгрунтованого змісту і засобів здійснення самостійної роботи; розподіл студентів за рівнями на основі існуючих відмінностей в особливостях і змісті самостійної навчально-пізнавальної діяльності, їх мотивації та умінні організовувати самостійну роботу; чітке уявлення кожним студентом того обсягу самостійних практичних робіт, який він має виконати за певний проміжок навчального часу (за семестр чи навчальний рік); ознайомлення студентів зі змістом передбачених для самостійної роботи практичних робіт; наявність зразків виконання практичних робіт i рекомендацій до них; знання вимог до оцінювання кожної роботи викладачем; можливість своєчасно отримати потрібну консультацію від викладача.

\section{Література}

1. Алексюк А. М. Педагогіка вищої освіти України. Історія. Теорія : [підручник] / А. М. Алексюк. - К. : Либідь, 1998. - 560 с.

2. Алексюк Л. Н. Организация самостоятельной работы студентов в условиях интенсификации обучения : [учеб. пособ. для слушателей ФПК] / Л. Н. Алексюк, А. А. Аюрзанайн, П. И. Пидкасистый, В. А. Козаков. - К., 1993. -336 с.

3. Болюбаш Я. Я. Організація навчального процесу у вищих закладах освіти / Я. Я. Болюбаш. - К. : Наукова думка, 1997. - 352 с.

4. Гончаренко С. У. Український педагогічний словник / С. У. Гончаренко. - К. : Либідь, 1997.- 367 с.

5. Мороз О. Г. Шляхи забезпечення наступності в самостійній навчальній роботі учнів середніх загальноосвітніх шкіл і студентів ВН3 : дис. ... канд. пед. наук: 13.00.01 / О. Г. Мороз. - К., 1972. -212 c.

Стаття надійшла до редакції 13.05.2012 p.

УДК [281.9:255]:37(477.8) “1921/1939”

C. В. Мишкарьова, aсnірант,

Рівненський державний гуманітарний університет

\section{МЕТОДОЛОГІЧНІ ЗАСАДИ ДОСЛІДЖЕННЯ ОСВІТНЬО-ВИХОВНӦ̈ ДІЯЛЬНОСТІ ПРАВОСЛАВНИХ БРАТСТВ У ЗАХІДНІЙ УКРАЇНІ У МІЖВОСННИЙ ПЕРІОД 1921-1939 рр.}

Мишкарьова С.В. Методологічні засади дослідження освітньо-виховної діяльності православних братств у Західній Украӥні у міжвоєнний період 1921-1939 рр.

У статті здійснено аналіз методологічних засад та основних теоретичних підходів до проблеми дослідження освітньо-виховної діяльності православних братств у Західній Украӥні у міжвоєнний період 1921-1939 рр., щзо використовуються в історії педагогіки як необхідні для иілісного і системного аналізу історико-педагогічних явищ і прочесів. 